\title{
A Case of Atypical Maxillary Sinusitis Accompanied with Papillon-Lefèvre Syndrome
}

\author{
Taejung Park and Boyoung Kim \\ Department of Otorhinolaryngology, Maryknoll Medical Center, Busan, Korea
}

\author{
Papillon-Lefèvre Syndrome에 병발한 비전형적 상악동염 1예 \\ 박 태 정·김 보 영 \\ 메리놀병원 이비인후과
}

Received January 17, 2013

Revised March 29, 2013

Accepted April 3, 2013

Address for correspondence

Boyoung Kim, MD

Department of Otorhinolaryngology,

Maryknoll Medical Center,

121 Junggu-ro, Jung-gu,

Busan 600-730, Korea

Tel $+82-51-465-2205$

Fax +82-51-461-0297

E-mail entkby@naver.com
Papillon-Lefèvre syndrome (PLS) is an extremely rare autosomal recessive disorder characterized by palmoplantar keratoderma and periodontitis and occuring with an estimated incidence of 1-4 cases per million. Patients with PLS are highly susceptible to infection. The etiology of an infective susceptibility is unknown; however, an association with defects in neurophil dysfunction, insufficient lymphocyte response to pathogens, defects in monocyte functions and impairment of NK cell cytotoxic function has been suggested. To our knowledge, this is the first case report of atypical maxillary sinusitis accompanied by PLS, and we represent the case with a review of the related literatures. Korean J Otorhinolaryngol-Head Neck Surg 2013;56:456-9

Key Words Maxillary sinusitis · Papillon-Lefèvre syndrome.

\section{서 론}

Papillon-Lefèvre syndrome(PLS)은 장척각화증(palmoplantar keratoderma)과 치근막염(periodontitis)을 특징으로 하는 상염색체열성질환으로 유병률은 인구 100만 명당 1 4명 으로 보고된 드문 질환이다. ${ }^{1)} \mathrm{PLS}$ 환자는 감염에 매우 취약한 데 ${ }^{2)}$ 그 이유는 아직까지 정확하게 밝혀지지 않았다. 그러나 호 중구 기능장애, 병원체에 대한 불충분한 림프구 반응, 단핵구 기능 결손, 그리고, $\mathrm{NK}$ 세포 독성 기능장애 등이 제시되었다.,4) 최근 본 저자들은 PLS 환자에서 동반된 비전형적 상악동염 1 예를 치험하였기에 문헌고찰과 함께 보고하는 바이다.

\section{증 례}

25세 여자 환자로 수개월간 급속히 진행된 우측 안와 주위 및 협부의 동통과 두통을 주소로 이비인후과 외래를 내원하 였다. 환자는 상기 증상으로 수주 전 개인 이비인후과에서 급 성 부비동염을 진단받아 항생제를 복용하였으나 증상의 호전
과 악화를 반복하였다. 처음 방문 당시 비내시경 소견상 우측 상악동 내 물질로 인해 상악동 내측벽이 비중격을 향해 돌출 되어 비강이 많이 좁아져 있는 상태로 중비도를 관찰하기 힘들 었으며, 좁아진 부위 뒤로 용종 및 짙은 색의 비루가 관찰되었 다(Fig. 1). 임상 검사소견상에서는 심전도, 완전혈구검사, 간 기능검사, 전해질검사, 뇨검사, $\mathrm{AIDS}$ 혈청검사상 모두 정상 소견을 보였으며, 비강 내 분비물 균배양 검사에서는 Staphylococcus lugdunensis가 동정되었다. 환자는 십 수년 전 장척 각화증과 치아 손실로 타 병원 피부과를 방문하여 시행한 치 과용 파노라마 X-선 촬영 및 피부 병변 조직검사 상 PLS로 진 단되어 보존적 약물치료 후 외래 추적 관찰을 자의 중단한 것 이외에는 다른 병력은 발견되지 않았다(Fig. 2).

부비동 전산화단층촬영상 중앙부의 석회화를 동반한 비균 질성 연조직 음영의 종물이 우측 상악동을 가득 채우고 있었 고, 이가 우측 비강 외측벽을 비중격을 향해 밀고 있었으나 뚜 렷한 상악동 내측 벽의 골파괴 소견은 보이지 않았다(Fig. 3). 부비동 자기공명영상에서 우측 상악동은 $\mathrm{T} 1$ 강조영상에서 낮 은 신호강도, T2 강조영상에서 더 낮은 신호강도를 보여(Fig. 4), 

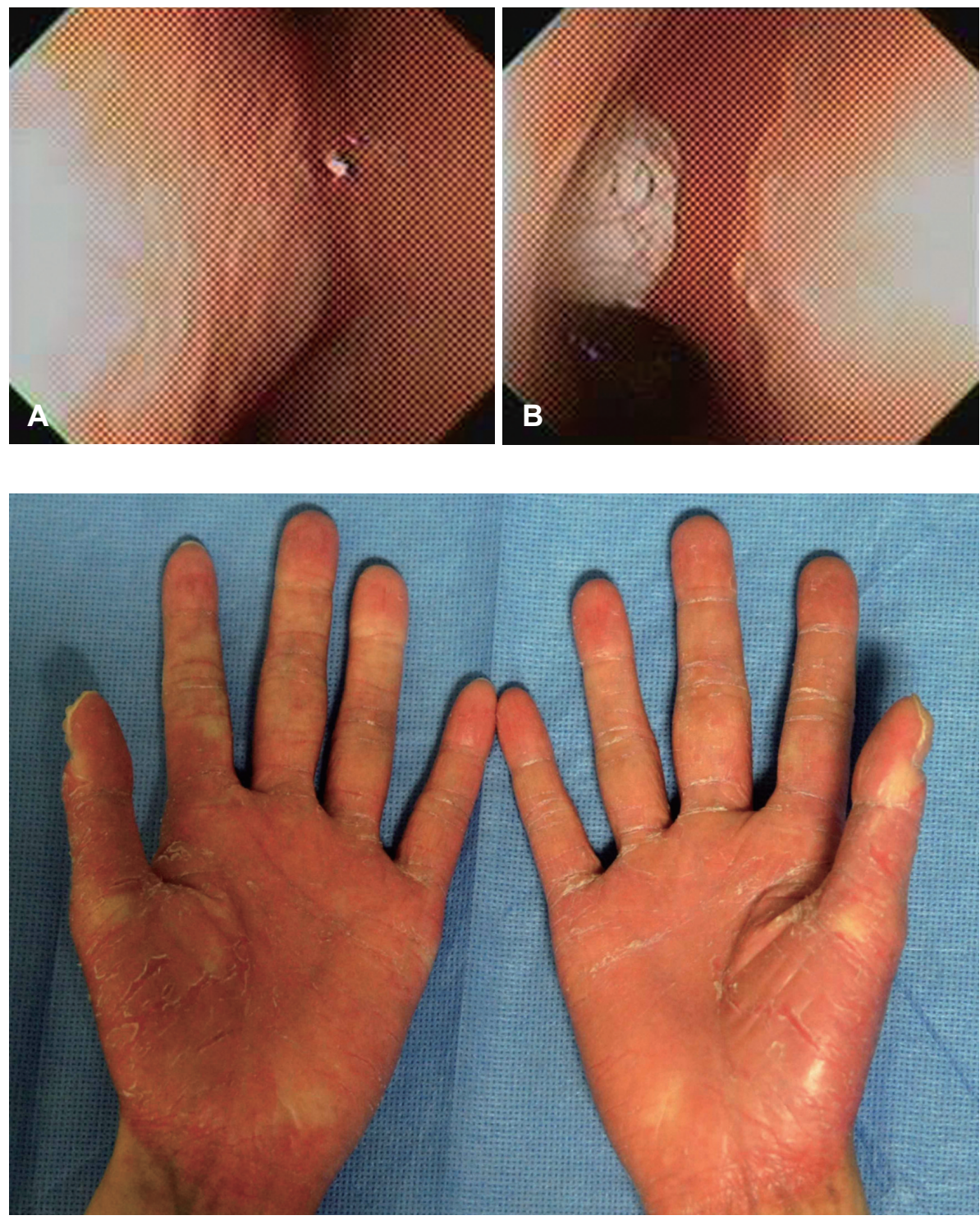

Fig. 1. Endoscopic photographs of right nasal cavity show medial wall of maxillary sinus bulge $(A)$ with inflamed mucosa and polyp (B).

Fig. 2. The patient had diffuse hyperkeratosis on entire surface of the palms.

우측 상악동의 진균성 부비동염 의심 하에 부비동 내시경 수 술을 시행하였다.

수술시 우측 중비도 입구에는 작은 비용종이 있었고, 우측 상악동 내에는 회백색의 종물 덩어리가 가득 채워져 있었으며 이는 가벼운 기구 조작에도 쉽게 부스러지는 양상이었다. 병 변을 조각조각으로 모두 제거 후 동결절편 조직검사를 시행 하였으나 균사는 전혀 보이지 않았고 비정형화된 염증 소견만 있다는 리포트를 받은 후, 상악동 개창술을 크게 시행하고 상 악동 세척을 하고 수술을 마쳤다.

술 후 영구 병리조직학적 소견상에서도 염증세포, 호중구성 삼출물, 괴사 등 만성 염증 소견은 있었지만 종양세포 및 진균 등은 발견되지 않았다(Fig. 5).

환자에게는 비전형적인 상악동염을 보인 양상이 PLS와의 연관성이 있을 수 있음을 설명하고, 현재는 수술 후 9달째로
병변 재발은 없는 상태이며 주기적으로 이비인후과 외래를 방 문하며 추적관찰 중이다.

\section{고 찰}

PLS는 염색체 11q14에 위치한 cathepsin C 유전자(CTSC) 변이에 의해 발생하는 상염색체열성질환으로 유병률은 100 만 명당 1 4명으로 보고되는 매우 드문 질환이다. ${ }^{3)} \mathrm{PLS}$ 는 장척 각화증과 치근막염을 특징으로 하는데 장척각화증은 주로 4세 이전에 발생하고 치근막염은 보통 3 4세 사이에 발생한 후 빠르게 진행하여 14 16세가 되면 영구적으로 치아 소실 상 태가 된다.) 본 증례의 환자도 장척각증이 있었고 진행된 치근 막염으로 영구적으로 치아가 모두 소실된 상태였다. 드문 형태 로 증상이 없는 대뇌겸, 소뇌천막, 맥락층의 석회화 등이 보고 
Fig. 3. Preoperative axial $(A)$ and coronal (B) CT scans. Expansible inhomogenous mass with focal calcification on right maxillary sinus caused nasal septal deviation.

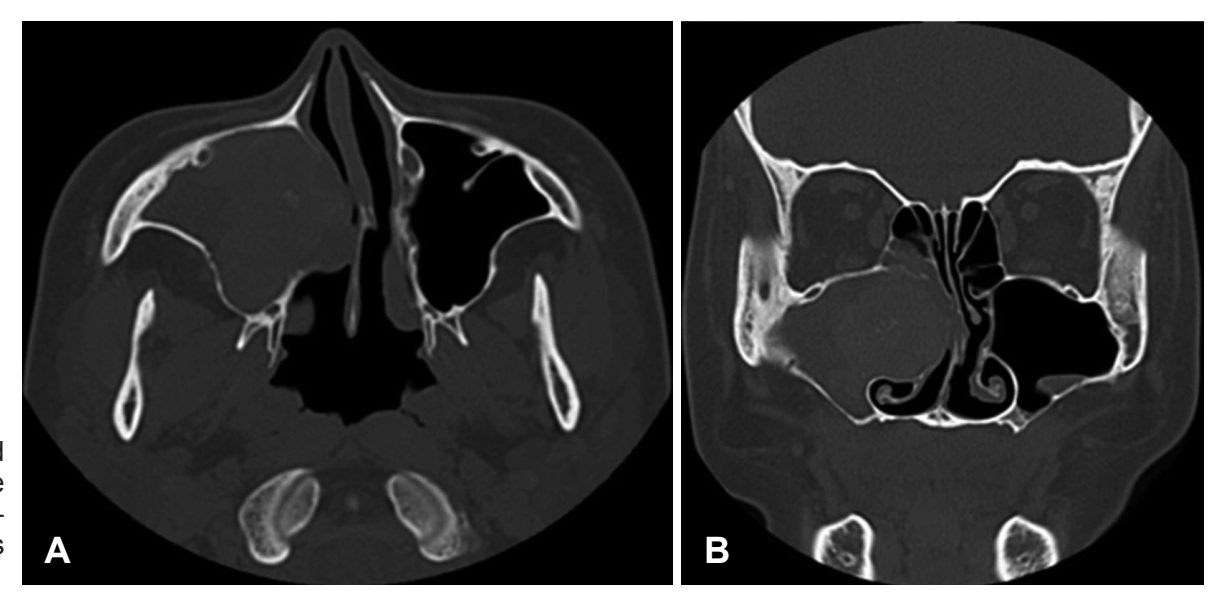

Fig. 4. Paranasal sinus MRI. T1weighted magnetic resonance image shows low signal mass occupies right maxillary sinus extends into nasal cavity without invasion to adjacent structures (A). It shows lower signal intensity than T1-weighted image on T2-weighted image (B).
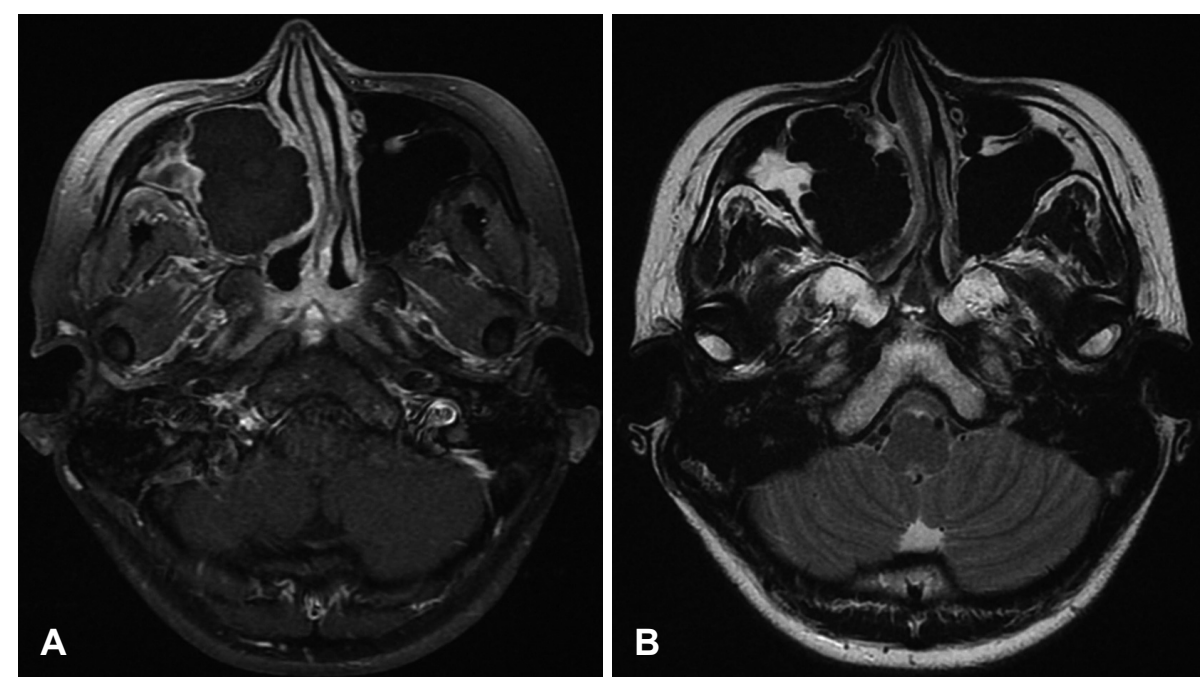

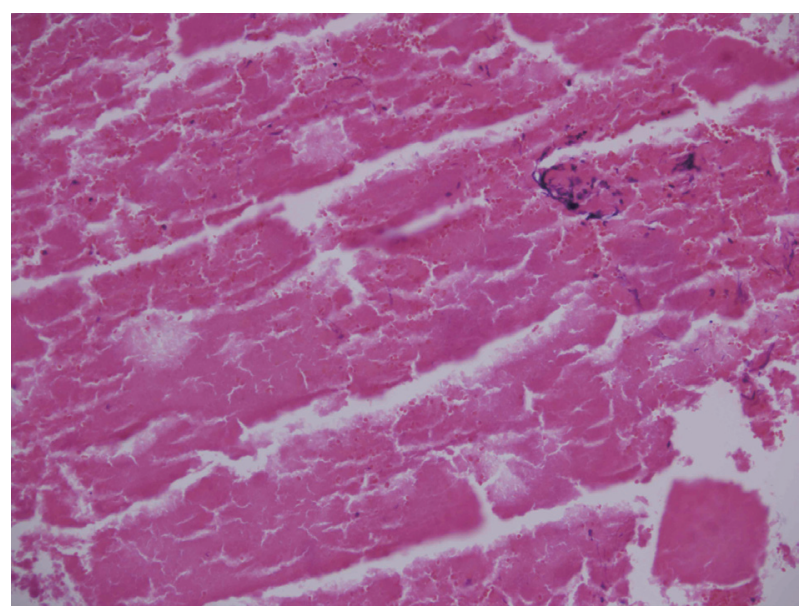

Fig. 5. Biopsy specimens showing mass of neutrophils surrounded by a granulomatous response (H\&E stain, $\times 100)$.

되어 있다. ${ }^{6}$ 최근 PLS 환자에서 간농양과 신장농양이 심각한 합병증으로 보고되면서 이 질환이 감염에 취약할 수 있음이 보 고되기 시작하였다.8) Almuneef 등ํ은 치주 염증에 의한 일시 적 균혈증과 함께 주화성(chemotaxis), 이주(migration), 식
균 작용(phagocytosis) 등과 같은 호중구 기능의 유전성 장애 때문에 감염에 대해 취약할 수 있음을 제시하였다. 그리고, Robert 등 ${ }^{8}$ 은 단순요로감염증 치료 2주 만에 신장농양이 형 성된 PLS 환자에게서 요로감염증과 신장농양 모두 Escherichia coli가 배양되었음을 지적하며 이 두 질환의 상관관계 의 가능성에 대해, 선행된 요로감염증의 혈행성 전파와 인접 한 미생물로부터의 감염 취약성을 주장하였다. 본 증례에서 의 우측 상악동염은 부비동 전산화촬영과 자기공명영상에서 는 일측성 진균성 부비동염이 강하게 의심되었으나, 수술시 소 견상 일반적인 상악동염에서 보이는 점막의 비후나 염증이 아 닌 회백색의 잘 부스러지는 균사 덩어리 같은 종물 형태가 관 찰되었다. 그러나 조직검사에서는 균사는 전혀 보이지 않는 호 중구 침착이 두드러진 만성 염증의 소견이었다. 저자들은 초 반에 이 질환에 대한 이해가 부족하였고 환자가 젊은 나이였 으며 가족력 및 과거 병력, 그리고 술 전 혈액검사에서 면역결 핍을 의심할 만한 특이 사항이 없었기에 진단 면역 검사를 시 행하지 않았고 따라서 환자의 면역결핍을 확신할 수는 없다. 그러나 비강내 분비물 균배양 검사에서 당뇨병성 케톤산증 
(diabetic ketoacidosis), 백혈구 감소증(neutropenia), 호중구 기능 저하증 그리고 영양실조증과 같은 면역결핍 환자에게 서 기회감염을 일으킬 수 있는 정상세균총인 Staphylococcus lugdunensis가 동정되었고, 젊은 나이임에도 빠른 기간 내에 일측성 상악동염이 상악동 내측벽을 비강을 향해 돌출될 정 도로 심하게 진행되었으며, 수술시 및 조직학적 소견상 일반 적인 상악동염에서 볼 수 없는 소견을 보이고 있으므로, PLS 가 비전형적 상악동염의 직접적인 원인임을 증명할 수는 없 지만, 충분한 상관관계는 있을 것으로 생각된다.

PLS는 현재까지 정립되어 있는 치료법이 없는 실정이고 대 부분에서 특별한 치료가 필요없지만 피부 증상은 대개 피부 연화 크림, 살리신산, 그리고 요소로 치료한다.5) 아시트레틴과 이소트레티노인(isotretinoin)과 같은 경구용 레티노이드(retinoid)가 각화증과 치근막염 모두의 치료에서 중심적인 역할 을 한다. ${ }^{6,10,11)}$ 예방적 항생제의 사용에 관하여 완전한 합의는 이루어지지 않았으나 ${ }^{12)}$ 본 증례처럼 상기도 감염이 동반된 경 우는 조기에 항생제를 사용하는 것이 증상 악화 및 여타 다른 합병증으로의 진행 억제에 도움을 줄 것으로 생각된다.

\section{REFERENCES}

1) Gorlin RJ, Sedano H, Anderson VE. The syndrome of palmar-plantar hyperkeratosis and premature periodontal destruction of the teeth. A clinical and genetic analysis of the Papillon-Lef'evre syndrome. J
Pediatr 1964;65:895-908.

2) Van Dyke TE, Taubman MA, Ebersole JL, Haffajee AD, Socransky SS, Smith DJ, et al. The Papillon-Lef'evre syndrome: neutrophil dysfunction with severe periodontal disease. Clin Immunol Immunopathol 1984;31(3):419-29.

3) Dalgıc B, Bukulmez A, Sarı S. Eponym: Papillon-Lefevre syndrome. Eur J Pediatr 2011;170(6):689-91.

4) Lundgren $T$, Parhar RS, Renvert $S$, Tatakis DN. Impaired cytotoxicity in Papillon-Lefèvre syndrome. J Dent Res 2005;84(5):414-7.

5) Siragusa M, Romano C, Batticane N, Batolo D, Schepis C. A new family with Papillon-Lefèvre syndrome: effectiveness of etretinate treatment. Cutis 2000;65(3):151-5.

6) Bergman R, Friedman-Birnbaum R. Papillon-Lefèvre syndrome: a study of the long-term clinical course of recurrent pyogenic infections and the effects of etretinate treatment. Br J Dermatol 1988;119(6): 731-6.

7) Oğuzkurt P, Tanyel FC, Büyükpamukçu N, Hiçsönmez A. Increased risk of pyogenic liver abscess in children with Papillon-Lefevre syndrome. J Pediatr Surg 1996;31(7):955-6.

8) Morgan RD, Hannon E, Lakhoo K. Renal abscess in PapillionLefèvre syndrome. Pediatr Surg Int 2011;27(12):1381-3.

9) Almuneef M, Al Khenaizan S, Al Ajaji S, Al-Anazi A. Pyogenic liver abscess and Papillon-Lefèvre syndrome: not a rare association. Pediatrics 2003;111(1):e85-8.

10) Nazzaro V, Blanchet-Bardon C, Mimoz C, Revuz J, Puissant A. Papillon-Lefèvre syndrome. Ultrastructural study and successful treatment with acitretin. Arch Dermatol 1988;124(4):533-9.

11) Nguyen TQ, Greer KE, Fisher GB Jr, Cooper PH. Papillon-Lefèvre syndrome. Report of two patients treated successfully with isotretinoin. J Am Acad Dermatol 1986;15(1):46-9.

12) Dhanawade SS, Shah SD, Kakade GM. Papillon-lefevre syndrome with liver abscess. Indian Pediatr 2009;46(8):723-5. 